\begin{tabular}{lrr}
\hline \hline VOLUME 2 & No. 1 (April 2019) & Page 1-8 \\
\hline \hline
\end{tabular}

\title{
Pengaruh Metode Mengajar Inquiry dan Minat Membaca Terhadap Kemampuan Menulis Cerita Pendek Siswa Kelas XI SMA Negeri Sekota Samarinda
}

\author{
Kukuh Elyana, St. Y. Slamet, Sarwiji Suwandi \\ Universitas Mulawarman \\ Universitas Sebelas Maret \\ Universitas Sebelas Maret \\ Email: kukuh.elyana@fkip.unmul.ac.id
}

\begin{abstract}
This research aims to find out the difference between teaching inquiry methods and teaching methods of two stay two strays; differences of students who have high and low interest in reading; as well as the interaction between teaching methods and reading interest in the ability to write short stories. The research method is a $2 \times 2$ factorial design experiment research, with the research population of all students of Samarinda City State High School. Research data is obtained through tests of writing short stories and reading interest questionnaires. Based on the analysis of data obtained results, there is a difference between students with teaching method inquiry and two stay two stray from the statistical results $\mathrm{Fh}=21.57>\mathrm{Ft}=4.01$; there is a difference in ability between students interested in high reading and low reading interest with statistical results Fh = $15.12>\mathrm{Ft}=4.01$; There is an interaction between teaching methods and reading interest in short story writing skills with statistical results $\mathrm{Fh}=6.41>\mathrm{Ft}=4.01$. The conclusion of this study is: the method of teaching inquiry is better than two stay two strays; high reading interest is better than low reading interest; there is also an interaction between teaching inquiry methods and reading interest in short story writing skills.
\end{abstract}

Kata kunci: learning, methods, inquiry, interest in reading, writing.

\section{PENDAHULUAN}

Salah satu fenomena dalam dunia pendidikan yang diamati oleh guru saat ini adalah bagaimana kecenderungan siswa malas untuk melakukan kegiatan menulis. Rasa malas yang melanda tersebut akhirnya membuat siswa malas untuk melakukan kegiatan menulis. Hal itu menjadi suatu momok bagi siswa untuk tidak melakukan kegiatan menulis karena menganggap tulisan yang mereka miliki tidak baik dan terkesan buruk. Kurang intensif dan seriusnya siswa setiap kegiatan menulis sekalipun pada ranah pembelajaran membuat masalah yang ada semakin parah. Akhirnya hal tersebut merambah pada aspek dan kemampuan siswa dalam mengungkapkan gagasan maupun pikiran.

Masalah tersebut diketahui juga merambah pada siswa khususnya di kota Samarinda. Sebuah rubrik di harian Samarinda Pos pada tanggal 15 Mei 2015 mengungkapkan bahwa tidak ada nilai 100 yang didapat oleh siswa SMA di Samarinda. Keadaan ini memiliki ketimpangan ketika dibandingkan dengan nilai di kota Balikpapan yang notabene merupakan kota satu provinsi dengan Samarinda. Bahkan kota Balikpapan yang bukan merupakan ibukota provinsi seperti halnya Samarinda memiliki nilai 
yang lebih baik dalam mata pelajaran bahasa Indonesia. Setelah ditelisik sedikit lebih jauh sesuai dengan data terakhir dari Pusat Penilaian Pendidikan (Puspendik) mengungkapkan masalah yang dihadapi siswa khususnya Kalimantan Timur ialah dalam hal mengungkapkan gagasan maupun mencari ide pokok, kalimat utama, dan kalimat penjelas yang ada pada suatu paragraf.

Pembelajaran menulis cerita pendek merupakan salah satu alternatif pilihan yang dimiliki oleh bidang bahasa dan sastra dalam menggali potensi yang dimiliki siswa. Pembelajaran tersebut menekankan pada penggunaan kemampuan berpikir analitis dalam mengemukakan gagasan berupa ide dan tema yang akan diangkat menjadi sebuah cerita. Penelitian oleh Karabutova (2015: 1662) mengungkapkan bahwa pembelajaran cerita pendek sangat baik digunakan dalam pembelajaran menulis karena mencakup aspek yang penting dalam mengungkapkan pemikiran siswa khususnya pada tatabahasa yang digunakan. Pembelajaran cerita pendek juga terbukti meningkatkan motivasi siswa dalam menggunakan kemampuan komunikatif yang dimiliki. Hal ini tentu merupakan langkah yang sangat baik dalam memunculkan kembali kemampuan berpikir untuk mengungkapkan gagasan yang dimiliki oleh siswa.

Minat membaca juga akan menjadi hal yang akan dilihat seberapa kuat pengaruhnya dalam pembelajaran menulis cerita pendek. Selain membutuhkan keterampilan menulis yang baik, seseorang yang memiliki minat membaca secara teori akan terus-menerus melakukan kegiatan tersebut tanpa diperintah dan dengan kemamuan sendiri. Minat membaca secara teori juga akan berpengaruh pada kemampuan menulis cerita pendek siswa jika ditinjau dari penguasaan kalimat, keteraturan isi cerita pendek, dan lain sebagainya. Diduga, minat membaca memberikan pengaruh yang kuat dalam kemampuan berpikir siswa untuk memproduksi bahasa. Pada akhirnya minat membaca akan membuat produksi kosakata dan kemampuan siswa dalam menulis cerita pendek akan semakin baik.

Tujuan yang ingin dicapai dalam penelitian ini adalah (1) Mengetahui ada tidaknya perbedaan kemampuan menulis cerita pendek antara yang diajar dengan metode mengajar inquiry dan metode mengajar two stay two stray; (2) Mengetahui ada tidaknya perbedaan kemampuan menulis cerita pendek antara yang memiliki minat membaca tinggi dan minat membaca rendah; dan (3) Mengetahui ada tidaknya interaksi antara metode mengajar dan minat membaca terhadap kemampuan menulis cerita pendek.

Kusmana (2014: 33) menerangkan bahwa cerita pendek merupakan karya sastra berbentuk prosa fiksi yang mengangkat suatu peristiwa sebagai tema sentralnya dan dapat dibaca dalam sekali pembacaan atau untuk mengisi waktu luang. Peristiwa yang ada akan menjadi pokok hal yang dibicarakan dalam cerita pendek tersebut karena hanya terdiri dari satu hal. Hal tersebut mengakibatkan cerita yang ada dalam cerita pendek tidak terlalu kompleks dan jumlah halamannya menjadi tidak terlalu panjang. Dengan begitu, waktu yang digunakan dalam membaca cerita pendek tidak terlalu lama. Itu pula sebabnya cerita pendek banyak digunakan untuk mengisi waktu luang pembaca.

Unsur menulis cerita pendek seperti diungkapkan Kasnadi dan Sutedjo (2010: 193) ialah (1) pemahaman terhadap komponen cerita pendek, (2) estetika sebuah cerita pendek, (3) pemahaman proses pembuatan garis besar cerita pendek, (4) proses penulisan cerita pendek, (5) editing dan perbaikan cerita pendek, (6) proses pengentasannya. Unsur menulis cerita pendek ini tidak diwajibkan untuk runtut namun akan lebih baik jika pengarang memahami unsur tersebut dan menggunakannya dengan melengkapi satu sama lain.

Nurgiyantoro (1988: 279) menjabarkan kemampuan menulis khususnya menulis karangan di sekolah harus memperhatikan beberapa aspek, antara lain: (1) kualitas dan ruang lingkup isi, (2) organisasi dan penyajian isi, (3) gaya dan bentuk bahasa, (4) mekanik: tata bahasa, ejaan, dan tanda baca, kerapian tulisan, dan kebersihan, serta (5) respon afektif guru terhadap karya tulis. Kualitas dan ruang lingkup isi menunjukan pemilihan tema dan relevasi dalam kalimat-kalimat yang digunakan. Aspek respon afektif guru dikaitkan dengan kapasitas guru sebagai pembaca yang tertarik, kurang, atau tidak tertarik pada isi karangan. Sementara itu, pada aspek yang lain telah banyak dijelaskan dalam bagian sebelumnya yaitu pada bagian unsur menulis cerita pendek.

Siklus kegiatan menemukan (inquiry) menurut Riyanto (2010: 171) terbagi atas 5 poin utama yaitu observation, questioning, hypotheses, data gathering, dan conclusion. Observation berhubungan dengan kegiatan mengamati, kegiatan tersebut merujuk pada melihat dan mengamati masalah yang ada dan perlu untuk dicarikan solusi penyelesaian. Questioning merujuk pada kegiatan bertanya, bertanya dalam hal merumuskan hal-hal apa yang perlu dicarikan solusi penyelesaian masalah. Hypotheses berkaitan 
dengan dugaan sementara, peserta didik akan menduga suatu penyelesaian masalah dengan teori maupun pengetahuan yang dimiliki. Data gathering berhubungan dengan pemerolehan data, dalam tahap ini akan dilihat keberhasilan atau ketepatan dari hipotesis yang telah dibuat. Conclusion sama artinya dengan kesimpulan, hasil akhir dari hal yang diamati sehingga membuahkan suatu keputusan dari penelitian.

Suryani dan Agung (2012: 87-88) menggambarkan metode mengajar two stay two stray merupakan bagian dari metode kooperatif struktural yang menekankan pada strukturstruktur khusus yang dirancang untuk mempengaruhi pola-pola interaksi siswa dengan maksud mengembangkan interaksi tradisional agar interaksi menjadi lebih bervariasi. Variasi interaksi diperlukan untuk memberikan kejutan bagi siswa agar pembelajaran tidak terpaku pada satu pola. Pada akhirnya, pembelajaran dengan variasi interaksi tersebut membuat pembelajaran menjadi lebih menyenankan dengan interaksi sosial yang lebih beragam. Artinya, lebih banyak siswa yang ditemui pada pembelajaran oleh siswa lain disertai dengan pertukaran informasi daripada hanya terpaku pada salah satu kelompok. Pola ini juga dapat diartikan sebagai pola bertukar pasangan jika hanya dilakukan oleh dua orang.

Langkah-langkah dalam melaksanakan metode ini antara lain: (1) Peserta didik bekerja sama dalam kelompok yang berjumlah 4 (empat) orang; (2) Setelah selesai, dua orang dari masingmasing menjadi tamu kedua kelompok yang lain; (3) Dua orang yang tinggal dalam kelompok bertugas membagikan hasil kerja dan informasi kepada tamu mereka; (4) Tamu mohon diri dan kembali ke kelompok mereka sendiri dan melaporkan temuan mereka dari kelompok lain; (5) Kelompok mencocokkan dan membahas hasil kerja mereka.

Minat diungkapkan oleh Jahja (2013: 63) sebagai sebuah dorongan yang menyebabkan terikatnya perhatian individu pada objek tertentu seperti pekerjaan, pelajaran, benda, dan orang. Oleh sebab itu, objek kajian minat dapat menjadi sangat luas dan bergantung pada arah dorongan yang dimiliki oleh seseorang. Selain itu, minat berhubungan dengan sesuatu yang menguntungkan dan dapat menimbulkan kepuasan serta motivasi bagi seseorang. Menguntungkan dalam hal ini bukan kecenderungan yang selalu bersifat materi namun juga unsur yang lebih bersifat kepuasan batin yaitu kesenangan pribadi. Bagi sebagian orang, sebuah kegiatan bisa jadi merupakan aktifitas tambahan yang terkesan biasa saja. Namun bagi seseorang yang benar-benar berminat pada hal tersebut, aktifitas yang dimaksud dapat menimbulkan kepuasan dan kesenangan yang besar.

\section{METODE PENELITIAN}

Penelitian ini dilakukan di SMA Negeri Sekota Samarinda, pada semester ganjil tahun pelajaran 2015/2016 selama bulan Juli 2015 April 2016. Metode yang digunakan dalam penelitian ini adalah eksperimen. Pada kelas eksperimen, siswa mengikuti pembelajaran dengan metode mengajar inquiry. Sementara itu, pada kelas kontrol, siswa mengikuti pembelajaran dengan menggunakan two stay two stray. Populasi yang menjadi subyek penelitian ini adalah siswa kelas XI SMA Negeri Sekota Samarinda dengan sampel ditentukan menggunakan simple random sampling. Simple random sampling ialah teknik sampling yang digunakan oleh peneliti dengan melakukan lotre terhadap semua populasi (Arikunto, 2005: 97). Hasil dari sampel acak tersebut mendapatkan dua sekolah yaitu SMA Negeri 3 dan SMA Negeri 1 Samarinda.

Analisis data dalam penelitian ini terdiri dari dua bagian yaitu analisis data deskriptif dan inferensial. Analisis data deskriptif dilakukan dengan menyajikan data melalui tabel distribusi frekuensi, kemudian dilanjutkan dengan perhitungan nilai sentral untuk melihat sebaran data dengan menghitung modus, median, mean. Selanjutnya, dapat dilihat variansi data dengan menggunakan range, varians, standar deviasi, dan koefisien variasi (Taniredja dan Mustafidah, 2012: 61). Analisis data inferensial adalah teknik analisis statistik yang digunakan untuk menganalisis data sampel dan hasilnya diberlakukan unuk populasi yang jelas, teknik pengambilan sampel dari populasi itu dilakukan secara random (Sugiyono, 2013: 209). Analisis ini dilakukan dengan terlebih dahulu dilakukan uji persyaratan sebagai syarat untuk uji hipotesis.

\section{HASIL DAN PEMBAHASAN}

Pada bagian ini akan dideskripsikan datadata distribusi frekuensi, hasil uji normalitas dan homogenitas data meliputi (1) nilai kemampuan menulis cerita pendek siswa yang diajar dengan metode mengajar konteksual inquiry (A1); (2) nilai kemampuan menulis cerita pendek siswa yang diajar dengan metode mengajar two stay two stray (A2); (3) nilai kemampuan menulis cerita pendek siswa yang memiliki minat membaca tinggi (B1); (4) nilai kemampuan menulis cerita pendek siswa yang memiliki minat membaca rendah (B2); (5) 
nilai kemampuan menulis cerita pendek siswa yang diajar menggunakan metode mengajar inquiry dengan minat membaca tinggi (A1B1); (6) nilai kemampuan menulis cerita pendek siswa yang diajar menggunakan metode mengajar inquiry dengan minat membaca rendah (A1B2); (7) nilai kemampuan menulis cerita pendek siswa yang diajar menggunakan metode mengajar two stay two stray dengan minat membaca tinggi (A2B1); dan (8) nilai kemampuan menulis cerita pendek siswa yang diajar menggunakan metode mengajar two stay two stray dengan minat membaca rendah (A2B2).

Berdasarkan data yang diperoleh diketahui kelompok A1, secara keseluruhan memiliki rentang (range) 24, dengan skor terendah 68 dan skor tertinggi 92. Kemampuan menulis cerita pendek siswa pada kelompok ini mempunyai nilai rata-rata (mean) sebesar 81,47; modus sebesar 82; median sebesar 82; varians sebesar 36,27; dan simpangan baku (standar deviasi) sebesar 6,02. Diketahui pula kelompok A2, secara keseluruhan memiliki rentang (range) 24 , dengan skor terendah 64,67 dan skor tertinggi 89. Kemampuan menulis cerita pendek siswa pada kelompok ini mempunyai nilai rata-rata (mean) sebesar 75,46; modus sebesar 76; median sebesar 75,5; varians sebesar 30,92; dan simpangan baku (standar deviasi) sebesar 5,56.

Selanjutnya diketahui kelompok B1, secara keseluruhan memiliki rentang (range) 25,67, dengan skor terendah 66,33 dan skor tertinggi 92. Kemampuan menulis cerita pendek siswa pada kelompok ini mempunyai nilai ratarata (mean) sebesar 80,98; modus sebesar 82; median sebesar 82 ; varians sebesar 48,84 ; dan simpangan baku (standar deviasi) sebesar 6,99. Diketahui pula B2, secara keseluruhan memiliki rentang (range) 20,67, dengan skor terendah 64,67 dan skor tertinggi 85,33. Kemampuan menulis cerita pendek siswa pada kelompok ini mempunyai nilai rata-rata (mean) sebesar 75,94; modus sebesar 78; median sebesar 76,67; varians sebesar 23,92; dan simpangan baku (standar deviasi) sebesar 4,89.

Diketahui pula, kelompok A1B1 secara keseluruhan memiliki rentang (range) 13, dengan skor terendah 79 dan skor tertinggi 92. Kemampuan menulis cerita pendek siswa pada kelompok ini mempunyai nilai rata-rata (mean) sebesar 85,62; modus sebesar 82; median sebesar 85,33 ; varians sebesar 14,33; dan simpangan baku (standar deviasi) sebesar 3,79. Kelompok A1B2 memiliki rentang (range) 17,33, dengan skor terendah 68 dan skor tertinggi 85,33. Kemampuan menulis cerita pendek siswa pada kelompok ini mempunyai nilai rata-rata (mean) sebesar 77,31; modus sebesar 78; median sebesar 77,67; varians sebesar 23,79; dan simpangan baku (standar deviasi) sebesar 4,88. Kelompok A2B1 memiliki rentang (range) 22,67, dengan skor terendah 66,33 dan skor tertinggi 89. Kemampuan menulis cerita pendek siswa pada kelompok ini mempunyai nilai rata-rata (mean) sebesar 76,33; modus sebesar 69,67; median sebesar 76,00; varians sebesar 40,62; dan simpangan baku (standar deviasi) sebesar 6,37. Kelompok A2B2 memiliki rentang (range) 17,67, dengan skor terendah 64,67 dan skor tertinggi 82. Kemampuan menulis cerita pendek siswa pada kelompok ini mempunyai nilai rata-rata (mean) sebesar 74,58; modus sebesar 76,67; median sebesar 75,00; varians sebesar 21,77; dan simpangan baku (standar deviasi) sebesar 4,67.

Uji persyaratan pada penelitian ini meliputi uji normalitas dan uji homogenitas varians data. Uji normalitas penelitian ini meliputi delapan kelompok, yaitu: (1) A1; (2) A2; (3) B1; (4) B2; (5) A1B1; (6) A1B2; (7) A2B1; dan (8) A2B2. Hasil uji homogenitas menunjukkan semua kelompok berada pada kelompok-kelompok yang normal. Pada kelompok A1, A2, B1 dan B2 secara berturut-turut mendapati nilai $\mathrm{L}_{0} 0,0652,0,0897$, 0,0749 , dan 0,01121 berada di bawah nilai $L_{t}$ sebesar 0,1610. Sementara itu pada kelompok A1B1, A1B2, A2B1, dan A2B2 secara berturutturut mendapatkan hasil 0,0982, 0,1501, 0,1006, dan 0,1015 berada di bawah $\mathrm{L}_{\mathrm{t}}$ sebesar 0,2200. Pada hasil uji homogenitas varians data juga mendapatkan hasil homogen pada setiap kelompok, yaitu: (1) A1:A2; (2) B1:B2; (3) A1B1:A1B2; (4) A1B1:A2B1; (5) A1B1:A2B2; (6) A1B2:A2B1; (7) A1B2:A2B2; dan (8) A2B1:A2B2 secara berturut-turut memiliki $\chi^{2}$ hitung sebesar 0,18, 3,61, 0,89, 3,63, 0,60, 0,99, 0,03, dan 1,34 lebih kecil daripada $\chi_{\text {tabel }}^{2}$ sebesar 3,84 .

Uji hipotesis dilakukan untuk mengetahui apakah hipotesis nol $\left(\mathrm{H}_{0}\right)$ yang telah diajukan diterima, atau sebaliknya pada taraf kepercayaan tertentu hipotesis alternatif $\left(\mathrm{H}_{1}\right)$ yang telah diajukan diterima. Pengujian hipotesis ini menggunakan teknik Analisis Varians Dua Jalur. Teknik analisis statistik tersebut digunakan untuk melihat perbedaan pengaruh baik karena adanya (1) perbedaan metode mengajar yang berlainan (inquiry - two stay two stray), (2) perbedaan minat membaca (tinggi - rendah), maupun (3) interaksi antara metode mengajar dan minat membaca. Berdasarkan analisis varians dua jalur diperoleh $F_{\text {hitung }}$ dari sumber variansi antarkolom (A) sebesar 21,57. Sementara itu $F_{\text {tabel }}$ dengan db pembilang 1 dan db penyebut 56 pada taraf $\alpha=0,05$ diketahui 
sebesar 4,01. Berdasarkan analisis varians dua jalur diperoleh $F_{\text {hitung }}$ dari sumber variansi antarbaris (B) sebesar 15,12. Sementara itu $F_{\text {tabel }}$ dengan db pembilang 1 dan db penyebut 56 pada taraf $\alpha=0,05$ diketahui sebesar 4,01. Berdasarkan analisis varians dua jalur diperoleh $\mathrm{F}_{\text {hitung }}$ dari sumber variansi interaksi $(\mathrm{AxB})$ sebesar 6,41. Sementara itu $F_{\text {tabel }}$ dengan $d b$ pembilang 1 dan $\mathrm{db}$ penyebut 56 pada taraf $\alpha=$ 0,05 diketahui sebesar 4,01.

Interaksi yang ada pada metode mengajar dan minat membaca terhadap kemampuan menulis cerita pendek akhirnya membuat penelitian ini diteruskan pada uji lanjut menggunakan uji Tuckey. Uji sel pertama, pada kelompok A1B1:A1B2. Hasil pengujian hipotesis ketiga untuk uji Tuckey diperoleh nilai $\mathrm{Qh}=6,42$ dan nilai $\mathrm{Qt}=3,01$ untuk taraf nyata $\alpha=0,05$ dengan $\mathrm{n}=15$. Uji sel kedua, pada kelompok A1B1:A2B1. Hasil pengujian hipotesis keempat untuk uji Tuckey diperoleh nilai $\mathrm{Qh}=7,18$ dan nilai $\mathrm{Qt}=3,01$ untuk taraf nyata $\alpha=0,05$ dengan $\mathrm{n}=15$. Uji sel ketiga, pada kelompok A1B1:A2B2. Hasil pengujian hipotesis kelima untuk uji Tuckey diperoleh nilai $\mathrm{Qh}=8,53$ dan nilai $\mathrm{Qt}=3,01$ untuk taraf nyata $\alpha=0,05$ dengan $\mathrm{n}=15$. Uji sel keempat, pada kelompok A1B2:A2B1. Hasil pengujian hipotesis keenam untuk uji Tuckey diperoleh nilai $\mathrm{Qh}=0,76$ dan nilai $\mathrm{Qt}=3,01$ untuk taraf nyata $\alpha=0,05$ dengan $\mathrm{n}=15$. Uji sel kelima, pada kelompok A1B2:A2B2. Hasil pengujian hipotesis ketujuh untuk uji Tuckey diperoleh nilai $\mathrm{Qh}=2,11$ dan nilai $\mathrm{Qt}=3,01$ untuk taraf nyata $\alpha=0,05$ dengan $\mathrm{n}=15$. Uji sel keenam, pada kelompok A2B1:A2B2. Hasil pengujian hipotesis kedelapan untuk uji Tuckey diperoleh nilai $\mathrm{Qh}=1,36$ dan nilai $\mathrm{Qt}=3,01$ untuk taraf nyata $\alpha=0,05$ dengan $\mathrm{n}=15$.

Melalui analisis deskripsi data yang diperoleh, nilai rata-rata kemampuan menulis cerita pendek siswa yang diajar dengan metode mengajar inquiry berbeda dengan metode mengajar two stay two stray. Nilai rata-rata kemampuan menulis cerita pendek siswa yang diajar dengan metode mengajar inquiry adalah sebesar 81,47 sedangkan dengan metode mengajar two stay two stray adalah sebesar 75,46 . Hasil perhitungan ini didukung oleh hasil analisis inferensial yang menyatakan bahwa terdapat perbedaan signifikan antara kemampuan menulis cerita pendek siswa yang diajar dengan metode mengajar inquiry dan kemampuan menulis cerita pendek yang diajar dengan metode mengajar two stay two stray. Dengan demikian, dapat disimpulkan bahwa dalam penelitian ini metode mengajar inquiry memberikan pengaruh yang lebih baik daripada metode mengajar two stay two stray terhadap kemampuan menulis cerita pendek siswa.

Kelompok siswa yang dilihat dari sisi minat membaca tanpa membedakan metode mengajar yang digunakan, dibedakan antara siswa yang memiliki minat membaca tinggi dan minat membaca rendah. Hasil dari analisis deskriptif mengindikasikan bahwa nilai rata-rata keterampilan berbicara siswa yang memiliki minat membaca tinggi adalah sebesar 80,98 sedangkan nilai rata-rata kemampuan menulis cerita pendek siswa yang memiliki minat membaca rendah adalah sebesar 75,94. Dilihat dari nilai rata-rata tersebut, nilai kemampuan menulis cerita pendek siswa yang memiliki minat membaca tinggi lebih baik daripada nilai rata-rata siswa yang memiliki minat membaca rendah. Dengan demikian dapat disimpulkan bahwa minat membaca mempengaruhi kemampuan menulis cerita pendek siswa.

Hasil penelitian ini memiliki kesamaan dengan penelitian terdahulu yang dilakukan sebelumnya. Penelitian yang dilakukan oleh Kellog (2008: 22) pada artikel berjudul "Training writing skills: A cognitive developmental perspective" dalam Journal of Writing Research mengemukakan bahwa kegiatan menulis merupakan proses berkelanjutan dari kemampuan berpikir yang akhirnya dituangkan dalam sebuah tulisan yang runtut dan sistematis. Bahan-bahan yang nantinya akan dituang menjadi sebuah karya tulis di dapat dari pengalaman empiris maupun dari bahan bacaan. Jadi, pada dasarnya keemampuan menulis merupakan sebuah proses menemukan atau mengumpulkan pengetahuan untuk kemudian diubah atau dirakit menjadi sebuah pemikiran. Hasil dari pemikiran tersebut yang akhirnya dituang ke dalam bentuk karya tulis.

Hasil penelitian Kellog seakan dikukuhkan oleh penelitian eksperimen yang dilakukan oleh Epting et al (2013: 252) dengan judul "Read and think before you write: Prewriting time and level of print exposure as factors in writing and revision" pada jurnal yang sama. Penelitian tersebut melakukan uji pada dua kelompok siswa, siswa yang diberi waktu berpikir dan juga membaca buku cetak sebelum menulis untuk mendapat inspirasi mengenai hal yang akan ditulis. Waktu berpikir (prewriting time) diberikan pada dua kelompok siswa, kelopok pertama mendapat waktu 10 detik sedangkan kelompok kedua mendapat waktu 70 detik. Selain itu dibedakan pula siswa dari bahan bacaan yang pernah dibaca, ada siswa yang jarang membaca buku dan siswa 
yang sering membaca buku. Hasil penelitian tersebut mendapati bahwa siswa yang mendapat waktu 70 detik sebelum menulis mendapat nilai rata-rata lebih tinggi dari siswa yang hanya mendapat waktu 10 detik. Selain itu, waktu jeda yang digunakan serta kesalahan kata yang dibuat oleh siswa dengan waktu 70 detik sebelum menulis lebih sedikit daripada siswa dengan waktu 10 detik sebelum menulis. Hasil memuaskan pada penelitian tersebut juga didapat pada siswa yang memiliki intensitas membaca tinggi daripada siswa dengan intensitas membaca rendah.

Penelitian yang dilakukan oleh Abalhassan (2014: 103) dengan artikel berjudul "Students Common Writing Problem \& Practices at King Abdul Aziz University: An Inquiry to Move a Writing Center From Conception Towards Conceptualization" ingin melihat kecenderungan masalah yang sering ditemui pada mahasiswa saat akan melakukan kegiatan menulis. Selain itu, penelitian tersebut ingin melihat apakah diperlukan sebuah lembaga penulisan (Writing Center) di sebuah universitas guna membantu mahasiswa dalam menemukan dan mengatasi masalah-masalah yang sering menghambat saat menulis. Hambatan-hambatan memang sering muncul pada calon penulis ketika akan melakukan sebuah kegiatan menulis seperti ide, kekurangpahaman siswa pada hal yang ingin ditulis, maupun sistematika kepenulisan. Simpulan dari penelitian tersebut menyatakan bahwa mahasiswa memang membutuhkan adanya lembaga penulisan. Lembaga penulisan akan membantu semaksimal mungkin masalah yang dihadapai mahasiswa dengan memberikan beberapa saran dan informasi yang dibutuhkan oleh mahasiswa. Hal ini juga diakibatkan oleh kesulitan yang kerap dihadapi mahasiswa dan akhirnya membuat mahasiswa terhambat menyelesaikan tugas-tugas yang harus dikerjakan.

Pada dasarnya, akan jauh lebih baik jika kemampuan menulis telah ditanamkan pada siswa sedini mungkin seperti yang ingin dilihat oleh Koster et al (2015: 267) pada hasil penelitiannya dengan judul "Teaching Children to Write: A Meta-analysis of Writing Intervention Research" dalam jurnal Journal of Writing Research. Penelitian tersebut melihat kurang suksesnya pengajaran menulis di Belanda, Untuk itu, peneliti melakukan eksperimen untuk melihat hal-hal apa saja yang sekiranya menjadi tambahan pemacu nilai siswa dalam menulis. Hal-hal yang sekiranya dapat menjadi tambahan tersebut antara lain, pengajaran struktur teks, strategi menulis, penetapan tujuan, kosakata, bantuan sesama (peer assistance), aktifitas tambahan sebelum menulis, maupun bantuan saat proses menulis.

Penelitian oleh McCutchen (2011: 58) yang berjudul "From novice to expert: Implication of language skills and writing-relevant knowledge of writing skill" menjelaskan pentingnya kemampuan berbahasa dan pengetahuan tentang hal yang akan ditulis. Untuk memulai suatu tulisan, dua hal itu merupakan hal yang harus diperhatikan. Kemampuan berbahasa yang cukup akan membuat tulisan mudah dimengerti dan dipahamai oleh pembaca. Pengetahuan mengenai hal yang ingin ditulis nantinya akan menjadi sumber inspirasi dalam penemuan ide. Selain itu, pengatahuan mengenai hal yang akan ditulis juga diibaratkan sebagai bahan dari tubuh tulisan yang ada. Bukan hanya sebagai sarana menemukan ide, namun juga menjadi rangkaian isi yang saling menjalin di dalam sebuah tulisan.

Dari beberapa pembahasan di atas, kita dapat menarik suatu garis besar bahwa kegiatan menulis memerlukan dua hal pokok. Pertama berkenaan dengan kemampuan berpikir kritis dan analisis, dan yang kedua berkaitan dengan kebiasaan membaca sebagai bagian dari proses pengumpulan ide untuk menulis. Hal itu menambah pemahaman kita bahwa kegiatan membaca memang sangat dibutuhkan dalam kegiatan menulis. Penelitian oleh Nasser (2013: 68) yang berjudul "A Literacy Exercise: An Extracurricular Reading Program as an Intervention to Enrich Student Reading Habits in Qatar" mengusahakan upaya-upaya dalam meningkatkan peningkatan kebiasaan membaca siswa. Peningkatan kebiasaan di sisi lain juga dimaksudkan meningkatkan minat, agar peningkatan kebiasaan selalu terjalin terus menerus tanpa ada paksaan untuk membaca. Hasil dari penelitian tersebut menunjukkan hasil yang memuaskan dalam meningkatkan kebiasaan membaca bagi siswa di Qatar.

Penelitian yang hampir serupa dengan penelitian oleh Nasser telah dilakukan Ransdell (2015: 33) dengan judul "Home Literacy, Summer School, and Kindergarten Readiness among Bilingual Preschoolers in Low-Income Families". Isi penelitian tersebut mengamati bagaimana peran kegiatan membaca di rumah (home literacy), dan sekolah musim panas (summer school) dapat menjadi sarana menggiatkan minat membaca pada siswa dengan ekonomi rendah. Hasil penelitian menyatakan minat membaca siswa yang mengikuti sekolah musim panas lebih baik daripada siswa dengan kegiatan membaca di rumah. Hal tersebut 
terjadi karena sekolah musim panas yang biasanya dilakukan selama dua bulan, mampu memberikan pemahaman lebih kepada siswa dalam kegiatan membaca. Randsell mengatakan bahwa kegiatan membaca di rumah dapat semakin dimaksimalkan dengan menambah intensitas kegiatan membaca. Untuk keluarga dengan ekonomi rendah, hal tersebut dapat disiasati dengan melakukan kegiatan membaca di rumah. Orang tua dapat menggunakan jasa perpustakaan umum sebagai upaya meningkatkan minat membaca anaknya.

Sward dan Nathanson (2011: 81) juga menyadari pentingnya kegiatan membaca bagi penulis dalam artikel penelitian berjudul " $A n$ Individualised Literacy Intervention for Low Progress Readers and Writers in the Foundation Phase" pada Journal for Language Learning. Penelitian ini berisi usaha yang dilakukan untuk meningkatkan kebiasaan membaca pada siswa di negara Afrika Selatan dengan minat membaca rendah melalui perlakuan yang diberikan. Sementara pada siswa dengan kebiasaan membaca tinggi tidak diberi perlakuan. Tujuannya adalah untuk memacu siswa dengan kebiasaan membaca rendah sehingga mampu mencapai nilai rata-rata teman sekelas mereka menggunakan kebiasaan membaca. Hasil penelitian menjelaskan bahwa kemampuan siswa memang cukup meningkat dalam perlakuan yang telah diberikan. Nilai yang diharapkan juga telah terpenuhi. Hanya saja, kelemahan terlihat pada guru yang kurang mengeksplorasi siswa dalam kegiatan membaca maupun menulis.

\section{KESIMPULAN}

Hasil analisis data penelitian yang dilakukan memperoleh simpulan sebagai berikut: Pertama, kemampuan menulis cerita pendek siswa yang diajar dengan metode mengajar inquiry lebih baik daripada two stay two stray. Artinya, metode mengajar memiliki pengaruh yang signifikan terhadap kemampuan menulis cerita pendek siswa. Hal ini terbukti dari uji hipotesis dengan menggunakan Analisis Varians Dua Jalur.

Kedua, kemampuan menulis cerita pendek siswa yang memiliki minat membaca tinggi lebih baik daripada kemampuan menulis cerita pendek siswa yang memiliki minat membaca rendah. Artinya, minat membaca memiliki pengaruh yang signifikan terhadap kemampuan menulis cerita pendek siswa. Hal ini terbukti dari uji hipotesis dengan menggunakan Analisis Varians Dua Jalur. Ketiga, terdapat interaksi antara metode mengajar inquiry dan minat membaca terhadap kemampuan menulis cerita pendek siswa. Berdasarkan simpulan di atas, hasil penelitian ini menunjukkan bahwa metode mengajar dan minat membaca berpengaruh terhadap kemampuan menulis certa pendek siswa.

Berdasarkan pada temuan empiris dalam penelitian ini, maka perlu diajukan saran-saran sebagai berikut: Pertama, bagi guru, menggunakan metode yang tepat dan menciptakan lingkungan yang kondusif agar siswa dapat mengembangkan kemampuan menulisnya dengan konsentrasi penuh serta senantiasa menggiatkan minat membaca siswa. Kedua, bagi kepala sekolah, hendaknya mendukung upaya penerapan metode mengajar yang bervariasi serta menyediakan fasilitas yang memadai baik baik bagi guru maupun siswa.

Ketiga, bagi pengawas sekolah, sesuai kapasitasnya sebagai penilai kegiatan dan kelengkapan sekolah, untuk lebih tanggap dalam melihat kebutuhan sekolah dan senantiasa meningkatkan mutu proses pembelajaran di sekolah yang menjadi wewenangnya.

Keempat, bagi peneliti lain yang sejalan dengan kajian ini, untuk mengadakan penelitian serupa dengan melibatkan lebih banyak variabel bebas (prediktor) yang diduga memberikan kontribusi yang sangat komprehensif. Penelitian tersebut nantinya dapat menjadi pembanding dan pembaharu dari penelitian-penelitian sebelumnya. Hal ini akan sangat bermanfaat baik bagi peneliti maupun guru pelaksana pembelajaran kemampuan menulis.

\section{REFERENSI}

Abalhassan, Khalid M. (2014). Students' Common Writing Problems \& Practices at King Abdulaziz University: An Inquiry to Move a Writing Center From Conception Towards Conceptualization. Studies in Literature and Language. Vol. 9 (3). pp. 94-107.

Arikunto, Suharsimi. (2005). Manajemen Penelitian. Jakarta: Rineka Cipta.

Epting, Kimberly. et al. (2013). Read and think before you write: Prewriting time and level of print exposure as factors in writing. Journal of Writing Research. Vol. 4 (3). pp. 239-259.

Jahja, Yudrik. (2013). Psikologi Perkembangan. Jakarta: Kencana.

Karabutova, E. (2015). Teaching Communicative Competence Based on the Schematic Structure of Stories (Story Grammar). International Journal of Science and Research. Vol. 4 (3). pp. 1659-1663. 
Kasnadi \& Sutedjo. (2010). Menulis Kreatif: Kiat Cepat Menulis Puisi dan Cerpen. Yogyakarta: Nadi Pustaka.

Kellog, Ronald T. (2008). Teaching children to write: A meta-analysis of writing intervention research. Journal of Writing Research. Vol. 7 (2). pp. 249-274.

Koster, Monica. et al. (2008). Training Writing Skills: A Cognitive Developmental Perspective. Journal of Writing Research. Vol. 1 (1). pp. 1-26.

Kusmana, Suherli. (2014). Kreativitas Menulis. Yogyakarta: Ombak.

McCutchen, Deborah. (2011). From Novice to Expert: Implication of Language Skills and Writing-Relevant Knowledge for Memory During of Writing Skills. Journal of Writing Research. Vol. 3 (1). pp. 51-68.

Nasser, Ramzi. (2013). Teaching A Literacy Exercise: An Extracurricular Reading Program as an Intervention to Enrich Student Reading Habits in Qatar. International Journal of Education \& Literacy Studies. Vol.1 (1). pp. 61-71.

Nurgiyantoro, Burhan. (1988). Penilaian dalam Pengajaran Bahasa dan Sastra. Yogyakarta: BPFE.

Ransdell, Sarah. (2015). Home Literacy, Summer School, and Kindergarten Readiness among Bilingual Preschoolers in Low-Income Families. International Journal of Education and Social Science. Vol. 2 (5). pp. 31-37.

Sugiyono. (2013). Metode Penelitian Pendidikan. Bandung: Alfabeta.

Suryani, Nunuk., dan Agung, Leo S. (2012). Strategi Belajar Mengajar. Yogyakarta: Ombak.

Swart, M. \& Nathanson, R. (2011). An Individualised Literacy Intervention for Low Progress Readers and Writers In The Foundation Phase. Per Linguam. Vol. 27 (2). pp. 67-86.

Taniredja, Turkin \& Mustafidah, Hidayati. (2012). Penelitian Kuantitatif. Bandung: Alfabeta. 